\title{
Bermedia Sosial \\ Dalam Perspektif Maqashid Syari'ah (Membangun Komunikasi Di Media Sosial Berdasarkan Etika)
}

\author{
1Iffatin Nur, ${ }^{2}$ Muhammad Ngizzul Muttaqin \\ 1,2 Pascasarjana Institut Agama Islam Negeri Tulungagung \\ Jl. Mayor Sujadi Timur No. 46, Kabupaten Tulungagung, Jawa Timur \\ E-mail: iffaeltinury@gmail.com, muttaqinizzul19@gmail.com
}

\begin{abstract}
Millennial era is always synonymous with the advancement of various lines of technology, including the development of modern telecommunications tools that lead to social media activities. Different groups almost enjoy today's social media activities without exception. However, the impact of social media activities has led to various aspects of positive progress as well as an effect on harmful elements in the form of mutual ridicule, hoax news, and so forth. Maqashid syari'ah as the final value of the provisions of the Islamic law that carries the amount of protection of personal interests and the public interest is expected to be a response to social media activities today. As a literature-based study and literature review, this paper is expected to be able to contribute ideas and provide a solution to the various negative impacts of social media activities that occur at this time.
\end{abstract}

Keywords: Social media; Islamic law; Maqashid syari'ah

\begin{abstract}
Abstrak
Era milenial selalu identik dengan kemajuan berbagai lini teknologi, tidak terkecuali berkembangnya alat telekomunikasi modern yang menimbulkan aktivitas media sosial. Aktivitas media sosial hari ini hampir dinikmati oleh berbagai kalangan tanpa terkecuali. Namun demikian, dampak dari aktivitas media sosial telah menimbulkan berbagai aspek kemajuan yang positif maupun berdampak pada aspek negatif berupa saling mencemooh, berita hoax dan lain sebagainya. Maqashid syari'ah sebagai nilai akhir dari ketentuan hukum Islam yang mengusung nilai perlindungan terhadap kepentingan pribadi dan kepentingan umum diharapkan bisa menjadi sebuah respon atas aktivitas bermedia sosial hari ini. Sebagai kajian berbasis literatur dan kajian pustaka, tulisan ini diharapkan mampu memberikan sumbangan pemikiran dan memberikan sebuah solusi atas berbagai dampak negatif dari aktivitas media sosial yang terjadi saat ini.
\end{abstract}

Kata Kunci,: Media sosial; Hukum Islam; Maqashid syari'ah 


\section{Pendahuluan}

Pada era globalisasi ini, penggunaan media sosial dalam berbagai aspek komunikasi di kehidupan manusia sudah pasti dibutuhkan. Dimulai dengan komunikasi obrolan untuk saudara, teman, keluarga, bahkan komunikasi dalam dunia pekerjaan telah menjamur dan mendarah daging bagi setiap elemen masyarakat. Akhirnya pemasangan koneksi-koneksi internet seakan hal yang maklum terjadi, rumah pribadi, kantor, toko hingga tempat peribadatan pun juga terhubung dengan koneksi internet. ${ }^{1}$ Akhirnya berdampak pada runtuhnya komunikasi menggunakan surat menyurat, dan beralih pada media komunikasi yang lebih modern, yang disebut dengan media sosial.

Penggunaan teknologi dalam komunikasi kini berjalan seiring dengan masa yang dibentuknya, sebuah momen dari kemajuan dan pesatnya teknologi komunikasi telah mampu menggeser masyarakat pada dunia tertentu menjadi sebuah satuan komunitas global tanpa tembok pembatas. Teknologi yang selama ini telah dituduh sebagai penyebab desosialisasi dalam kehidupan masyarakat modern, kini tampil menjadi ruang sosialisasi baru yang sangat efektif menjalin berbagai hubungan-hubungan sosial. Media sosial yang menjadi tanda kemajuan teknologi komunikasi kini tampil sebagai simulasi kehidupan tanpa memandang batas-batas tutorial. Seseorang boleh jadi lebih dekat secara sosial dan jauh secara tutorial dengan seseorang, ketimbang seseorang yang dekat secara tutorial, akan tetapi jauh secara sosial. ${ }^{2}$

Keberadaan media hari ini telah memalingkan dari interaksi komunikasi interpersonal pada dunia nyata menuju interaksi pada dunia maya. Melalui media sosial, setiap pemilik akun bisa mengesankan darinya menjadi baik maupun buruk, di mana pada umumnya setiap orang ingin dikenal baik. Banyak orang yang kurang popular di lingkungan sosial masyarakatnya, namun mempunyai kebutuhan untuk menjadi popular, maka media sosial sebagai alternatif solusinya. Dalam kondisi demikian, ada sebagian orang yang menyalahgunakan media sosial untuk kepentingan tertentu, dan sebagian yang lain menjadi korban atas penyalahgunaan tersebut. $^{3}$

Interaksi secara tidak langsung ini tentu mempunyai dampak yang positif maupun negatif. Beberapa diantara yang positif adalah terbentuknya

\footnotetext{
${ }^{1}$ Subehan Khalik, "Hukum Islam dan Penggunaan Telematika di Indonesia", al-Daulah: Jurnal Hukum Pidana dan Ketatanegaraan, Volume 1, Nomor 1, 2012, 63.

${ }^{2}$ Aswan, "Tekno-Culture: Memahami Kondisi Masyarakat Masa Depan", Palita: Journal of Social-Religion Research, Volume 2, Nomor 1, April 2017, 27.

${ }^{3}$ Siti Khoirotul Ula, "Fikih Media Sosial Sebagai Landasan Etika Komunikasi On-Line", Peoceedings Ancoms 2017, UIN Sunan Ampel Surabaya, 347-348.
} 
komunitas pelajar, bisnis, dan beberapa hal positif lainnya. Meskipun demikian, gejala-gejala perselisihan dan perpecahan yang diakibatkan dari interaksi menggunakan media sosial juga tidak kalah banyaknya. ${ }^{4}$ seperti berita bohong menjadi marak akibat rendahnya penyaringan masyarakat terhadap informasi yang diterima di media sosial.

Dalam konten media sosial, pengguna media sosial memberikan berita, baik fakta maupun pendapat pribadi tentang kehidupannya sendiri maupun berkomentar tentang kehidupan orang lain. Pada dasarnya berita atau kabar bersifat fakta, ${ }^{5}$ namun dalam kenyataannya ini yang diartikan oleh pengguna media sosial. Berita hoax, menghujat kelompok lain, bahasa kasar yang menyinggung perasaan orang lain, cemoohan dan lain sebagainya, sudah menjadi hal yang menjamur dalam dunia komunikasi sosial media hari ini.

Dalam kondisi lain, era media sosial seperti sekarang ini juga menimbulkan suatu ketakutan. Semua masyarakat bisa menjadi sasaran dampak langsung dari maraknya media sosial. Apalagi jika komunikasi dalam media sosial sudah beralih fungsi menjadi media untuk menista kelompok lain, seperti suku, agama, ras. ${ }^{6}$ Hal ini tentu akan menimbulkan sebuah gejolak yang sangat hebat, seperti pertikaian antar kelompok, bentrok, dan lain sebagainya.

Hal ini diperparah sepanjang tahun 2019 yang menjadi tahun demokrasi Indonesia, pada kurun waktu satu minggu saja (21 hingga 28 Mei 2019) POLRI telah menangkap 10 tersangka penyebar berita kebohongan dan ujaran kebencian. ${ }^{7}$ Kejadian semacam ini tentu sangat mengkhawatirkan keutuhan Negara dan kerukunan antar pribadi maupun kelompok.

Salah satu tokoh yang fokus dalam bahasan maqashid syari'ah adalah Ibn 'Asyur, di mana dalam pemikiran Ibn 'Asyur maqashid syariah memiliki suatu universalitas yang harus diwujudkan melalui pelaksanaan syariat Islam. Dalam universalitas tersebut mencakup mewujudkan kemaslahatan secara pribadi maupun secara umum. ${ }^{8}$ Dalam konteks dampak negatif yang diakibatkan oleh aktivitas media sosial hari ini diperlukan sebuah analisis baru menggunakan konsep maqashid syari'ah, agar tidak terjadi pelanggaran

\footnotetext{
${ }^{4}$ Apriadi Tamburaka, Literasi Media: Cerdas Bermedia Khalayak Media Massa. (Jakarta: Raja Grafindo Persada, 2003), 222.

5 Jani Josef, To Be A Jurnalist: Menjadi Jurnalis TV, Radio, dan Surat Kabar Yang Profesional. (Jogjakarta: Graha Ilmu, 2009), 22.

${ }^{6}$ Arif Alfani dan Hasep Saputra, "Menghujat dan Menista di Media Sosial Perspektif Hukum Islam”, Al-Istimbath: Jurnal Hukum Islam, Volume 4, Nomor 1, 2019, 36.

${ }^{7}$ Kompas.com, Sejak 21 Mei, Polri Tangkap 10 Tersangka Penyebar Hoaks dan Ujaran Kebencian, kabar pada hari, Selasa, 28 Mei 2019.

8 Chamim Tohari, "Pembaharuan Maqashid al-Syari'ah Dalam Pemikiran Muhammad Thahir Ibn 'Asyur", Al-Maslahah: Jurnal Ilmu Syariah, Volume 13, Nomor 1, April 2017, 22.
} 
menggunakan media sosial, baik pelanggaran yang menciptakan mafsadat secara pribadi maupun mafsadat secara umum.

\section{Metode}

Penelitian ini dilakukan dengan cara mengkaji naskah para ulama' tentang maqashid syari'ah yang terdapat dalam kitab-kitab (turast) dari beberapa generasi yang membahas tentang maqashid syari'ah. Studi dokumen dikelompokkan ke dalam tiga kategori sumber data. ${ }^{9}$ Pertama, sumber hukum primer, yaitu bahan bacaan yang sifatnya mengikat masalahmasalah tentang maqashid syari'ah, seperti kitab al-Muwafaqat karya alJuwaini, Maqashid Syari'ah al-Islamiyah karya Ibn Asyur. Kedua, sumber hukum sekunder, yaitu sumber data yang memberikan penjelasan tentang bahan hukum primer, yaitu kitab-kitab ulama' kontemporer yang menjelaskan tentang maqashid syari'ah, karya ilmiah, dan hasil penelitian dari para sarjana. Ketiga, sumber hukum tersier, yaitu bahan data yang memberikan informasi tentang sumber hukum primer dan sekunder, seperti ensiklopedi hukum dan jurnal-jurnal ilmiah. Kemudian data dianalisis dengan menggunakan analisis konten (content analysis).

\section{Bermedia Sosial: Antara Maslahah Dan Mafsadat}

Islam pada dasarnya menyerukan umat manusia untuk menjalin hubungan dengan manusia lain, atau yang terkenal dengan habl min al-nass. Sebagai tuntutan sebagai manusia yang beragama serta tuntutan sebagai makhluk sosial, berkomunikasi sudah menjadi kelayakan khusus bagi setiap manusia. Namun, berkomunikasi tidak hanya sekedar berkomunikasi, berkomunikasi tentu mempunyai rambu-rambu yang tidak boleh dilanggar oleh manusia. ${ }^{10}$ Agama Islam mengajarkan untuk berkomunikasi yang baik, santun, tidak menyakiti lawan berkomunikasi, serta tidak berbohong. ${ }^{11}$

Dalam era milenial hari ini, berkomunikasi sudah menjadi keumuman dalam dunia media sosial. Media sosial adalah media berbasis Internet yang memungkinkan pengguna berkesempatan untuk berinteraksi dan mempresentasikan diri, baik secara mendadak maupun tertunda, dengan khalayak luas maupun tidak yang mendorong nilai dari user generated content dan persepsi interaksi dengan orang lain. ${ }^{12}$

\footnotetext{
${ }^{9}$ Lebih jelas tentang penjelasan sumber hukum primer, skunder, tersier. Lihat pada, Zainuddin Ali, Metode Penelitian Hukum, 47-57.

10 Fajrina Eka Wulandari, "Hate Speech Dalam Pandangan UU ITE Dan Fattwa MUI", Ahkam: Jurnal Hukum Islam, Volume 5, Nomor 2, November 2017, 260.

${ }^{11}$ Lihat, QS. An Nuur (24) ayat 16.

12 Hendra A. Setyawan, "Fikih Informasi Di Era Media Sosial Dalam Membangun Komunikasi Beretika (Studi Kajian Fikih Informasi Sudut Pandang Ormas Muhammadiyah",
} 
Saat ini perkembangan komunikasi yang ditandai oleh maraknya aplikasi media sosial seperti Whatsapp, Twitter dan Facebook, mengalami perkembangan yang sangat pesat pada semua lini kalangan. Sebagai aplikasi media sosial, hal ini tentu menimbulkan dampak baru, baik dampak positif maupun negatif. Dampak positif dari adanya media sosial dalam perkembangan telekomunikasi sebenarnya membawa banyak keuntungan, sebagai contoh untuk memudahkan dalam hal komunikasi, memeroleh informasi, berbisnis, dan lain sebagainya.

Whatsapp, Twitter, Facebook serta situs jejaring media sosial lain, saat ini merupakan sebuah aplikasi yang sangat digemari oleh semua kalangan. Dengan bantuan situs jejaring ini, semua orang bisa memperluas pertemanan, baik secara kekerabatan maupun dengan orang lain dan masyarakat luas. Bukan hanya dalam ruang lingkup lingkungan sekitar tempat tinggal saja, akan tetapi dari berbagai kalangan lingkungan yang lebih jauh, bahkan dalam tingkat negara maupun internasional.

Namun demikian, ada pula dampak negatifnya, di antaranya; berkurangnya interaksi interpersonal secara langsung, menyebabkan kecanduan, serta persoalan etika dan hukum, dikarenakan kontennya yang mengandung pelanggaran moral, privasi, dan peraturan pemerintah (UU ITE). Sehingga, pada ujungnya akan melahirkan budaya baru pada masyarakat tentang pemanfaatan waktu tanpa didampingi oleh media sosial. Pengguna media sosial pada saat ini tidak hanya dilakukan pada waktu luang saja, namun juga dilakukan juga pada waktu-waktu sibuk, karena dimanfaatkan sebagai sarana untuk bekerja. ${ }^{13}$

Batasan waktu, ruang dan jangkauan menjadi hilang, sehingga gaungnya pun menjadi luas tanpa adanya sekat seperti pada efek dari media konvensional. Oleh karenanya, kearifan dalam pemakaian media sosial harus dipertimbangkan karena dampaknya sangat sulit diprediksi dan dideteksi, apalagi kalau kontennya melanggar kepatutan, etika, norma-norma masyarakat, budaya dan lainnya.

\section{Maqashid Syari'ah: Mengambil Maslahah Dan Menciptakan Kemaslahatan Umat}

Dalam memaparkan hakikat maqashid syari'ah, peneliti berpendapat bahwa esensi maqashid al-syari'ah adalah kemaslahatan dari taklif Tuhan

Disampaikan Dalam Seminar Nasional Tentang "Membangun Etika Sosial Politik Menuju Masyarakat Yang Berkeadilan", yang dilaksanakan oleh FISIP Universitas Lampung Pada Tanggal, 18 Oktober 2017 di Hotel Swiss Bell, Bandar Lampung, 151.

13 Eko Sumadi, "Dakwah Dan Media Sosial: Menebar Kebaikan Tanpa Diskriminasi”, AtTabsyir: Jurnal Komunikasi Penyiaran Islam, Volume 4, Nomor 1, Juni 2016, 185-186. 
dapat berwujud hakiki, yakni manfaat langsung dalam arti kausalitas hukum dan majazi atau sebab yang membawa kemaslahatan. ${ }^{14}$ Kemaslahatan dapat dianalisis melalui beberapa sudut pandang yaitu Maqashid al-Syari' (Tujuan Tuhan) dan Maqashid al-Mukallaf (Tujuan Mukallaf). ${ }^{15}$

Hal itu bertujuan agar jangan sampai orang yang melakukan ijtihad (penggalian maupun penerapan hukum) "terperangkap" pada hukum-hukum yang bersifat partikular (juz'iyat) semata dan mengabaikan maqashid alsyari'ah. Dalam kaitan ini, Yusuf al-Qardlawi, mengingatkan dengan mengatakan:

$$
\begin{aligned}
& \text { لهذا كان العلم بمقاصد الثريعة فى غاية الأهمية حتى لا يغلط عليها الغالطون ويجروا ور اء } \\
& \text { الأحكام الجزئية مهملين المقاصد الكلية فيخلطون ويخبطون. }
\end{aligned}
$$

Mengetahui tujuan (maqashid al-syari'ah) merupakan suatu hal yang penting, agar seseorang tidak terjebak dalam kesalahan dengan hanya memperhatikan hal-hal (hukum-hukum) yang bersifat parsial (juz'i), tanpa mengindahkan maksud hukum-hukum yang bersifat universal (kullî). Akibatnya, akan membawa kepada pencampuradukan hukum dan kebingungan.

Maqashid al-Syari'ah, dalam pandangan al-Syatibi mengandung empat aspek; pertama, tujuan awal dari syariat yakni kemaslahatan manusia di dunia dan di akhirat, yang merupakan hakikat maqashid al-syari'ah, kedua syariat sebagai sesuatu yang harus dipahami, aspek kedua ini berkaitan dengan dimensi bahasa agar syariat dapat dipahami sehingga dapat terwujud kemaslahatan yang dikandungnya. Ketiga Syariat sebagai suatu hukum takflif yang harus dilakukan, aspek ini berkaitan dengan pelaksanaan ketentuanketentuan syariat dalam rangka mewujudkan kemaslahatan dan barkaitan dengan kemauan manusia untuk melaksanakannya. Keempat, tujuan syariat adalah membawa manusia dalam naungan hukum, aspek ini berkaitan dengan kepatuhan manusia sebagai mukallaf di bawah dan terhadap hukumhukum Allah dan pembebasan manusia dari kekangan hawa nafsu. ${ }^{17}$

Dalam rangka mengklasifikasikan maqashid al-syari'ah, aspek pertama sebagai aspek inti menjadi fokus analisis, karena berkaitan dengan hakikat pemberlakuan syariat oleh Tuhan yakni kemaslahatan. Kemaslahatan akan terwujud apabila kelima unsur pokok dapat terpelihara. Kelima unsur pokok

14 Husein Hamid Hasan. Nadzariyah al-Maslahah Fi al-Fiqh al-Islamiy. (Beirut: Muassasah al-Risalah, 2001), 5

${ }^{15} \mathrm{Abu}$ Ishaq al-Syatiby. Al-Muwafaqat Fi Ushul al-Syari'ah. (Beirut; Dar al-Ma'rifah, 2000), 5.

16Yusuf al-Qardlawi, al-Ijtihad Fî al-Syari'ah al-Islamiyyah Ma'a Nazhrati Tahliliyat Fî alIjtihad al-Mu'ashir. (Kuwait: Dar al-Qalam, 2000), 44.

${ }^{17} \mathrm{Abu}$ Ishaq al-Syatiby, ...................., al-Muwafaqat, 6-10. 
itu, kata al-Syatibi adalah agama, jiwa, keturunan, akal dan harta. ${ }^{18}$ Pada dekade selanjutnya Ibnu 'Asyur menambahkannya dengan terpeliharanya kehormatan manusia (hifdz al-'irdh). ${ }^{19}$ Sementara Yusuf Qardhawi dalam Risalah fi Riayah al-biah menambahkannya dengan terpeliharanya keseimbangan ekosistem lingkungan (hifdz al-bi'ah). ${ }^{20}$

Dalam usaha memelihara ketujuh pokok diatas, diperlukan stratifikasi berikut; Maqashid al-Daruriyat, Maqashid al-Hajiyat, dan, Maqashid alTahsiniyat. Maqashid al-Daruriyat dimaksudkan untuk memelihara lima unsur pokok dalam kehidupan manusia di atas, maqashid al-hajiyat dimaksudkan untuk menghilangkan kesulitan atau menjadikan pemeliharaan terhadap tujuh unsur pokok menjadi lebih baik lagi. Sedangkan maqashidtahsiniyat dimaksudkan agar manusia dapat melakukan yang terbaik untuk penyempurnaan pemeliharaan tujuh unsur pokok. Tidak terwujudnya aspek daruriyat dapat merusak kehidupan manusia dunia dan akhirat secara keseluruhan. Pengabaian terhadap aspek hajiyat, tidak sampai merusak keberadaan tujuh unsur pokok, akan tetapi hanya membawa kepada kesulitan bagi manusia sebagai mukallaf dalam merealisasikannya. Sedangkan pengabaian aspek tahsiniyat, membawa upaya pemeliharaan tujuh unsur pokok tidak sempurna. Sebagai contoh, dalam memelihara unsur agama, aspek daruriyat-nya antara lain mendirikan salat, keharusan menghadap ke kiblat merupakan aspek hajiyat, dan menutup aurat merupakan aspek tahsiniyat. ${ }^{21}$

Apabila dianalisis lebih jauh, dalam usaha mencapai pemeliharaan tujuh unsur pokok secara sempurna, maka ketiga tingkat maqashid di atas, tidak dapat dipisahkan. Tingkat hajiyat adalah penyempurna tingkat daruriyat, tingkat tahsiniyat merupakan penyempurna bagi tingkat hajiyat, sedangkan daruriyat menjadi pokok hajiyat dan tahsiniyat.

\section{Etika Bermedia Sosial Perspektif Maqashid Syari'ah}

Kondisi saat ini menunjukkan bahwa fenomena yang berkembang dalam dunia komunikasi tidak bisa disangkal oleh perilaku media sosial. Istilah media sosial telah mengalami pertumbuhan yang amat popular di kalangan pengguna internet, terutama dalam penggunannya yang amat

${ }^{18}$ Lima unsur pokok di atas, dalam literatur-literatur hukum Islam lebih dikenal dengan Ushul al-Khamsah dan susunannya adalah agama, jiwa, akal, keturunan dan harta. Dengan perkembangan yang ditawarkan Ibnu asyur dan Yusuf Qardhawi maka terjadi perubahan substansi nama menjadi Ushul al-Sab'ah.

19 Muhammad Thahir Ibnu Asyur, Maqashid al-Syari'ah Al-Islamiyah. (Beirut: Dar alQalam, 2009), 175.

20 Yusuf Qardlawi, al-Ijtihad fî al-Syari'ah ................., 44, 45

${ }^{21}$ Bandingkan dengan Ali Hasaballah, Ushul al-Tasyri' al-Islam. (Mesir: Dar al-Ma'arif, 2003), 297. 
universal dan luas oleh semua kalangan. Media sosial telah mengubah secara drastis cara berkomunikasi dan kekuatan media sosial memungkinkan kita untuk tetap berhubungan dengan kejadian terbaru di seluruh dunia dalam hitungan detik atau menit. ${ }^{22}$

Komunikasi dalam media sosial sering dilakukan menggunakan bahasa non-standar. Salah satu alasannya adalah bahwa di dunia maya sering kali tidak jelas siapa lawan komunikasinya, meskipun ada juga yang sudah berinteraksi serta bertemu dalam dunia nyata dan melanjutkan komunikasi ke dalam dunia maya (media sosial). Sementara itu dalam penggunaan bahasa komunikasi dalam media sosial tidak menggunakan bahasa resmi, sebagaimana menulis pada karya ilmiah. Dalam penggunaan bahasa dalam media sosial sangat sedikit bahkan tidak pernah ada pengguna media sosial yang menulis status dengan menggunakan ejaan yang disempurnakan (EYD), padahal penulisan yang baku sangat penting dilakukan karena berkaitan dengan penggunaan etika dalam berkomunikasi antar pengguna media sosial.

Media sosial hari ini menjadi tempat untuk menumpahkan semua cerita dan keluh kesah dari semua aktivitas penggunanya, ledakan emosi dalam bentuk tulisan maupun foto yang mengesampingkan etika yang ada. Media sosial tidak lagi merupakan media yang digunakan untuk berbagi informasi, namun hanya menyebarkan berbagai sensasi. Jika kemajuan teknologi tidak dibarengi dengan kemajuan dalam berpikir, maka kemajuan teknologi akan berbanding terbalik dengan pola berpikir.

Perkembangan teknologi yang ditandai oleh maraknya aktivitas dalam dunia maya (media sosial) telah membuat pergeseran dalam hal pemikiran. Etika yang dulu dianggap sebagai hal yang amat penting oleh bangsa Indonesia, seakan menjadi sesuatu yang tidak penting lagi karena tuntutan zaman. Hal ini dibuktikan dengan aktivitas mengakses dan menggunakan media sosial tanpa disadari telah menjebak dalam hal penurunan etika.

Dalam kehidupan bersosial di masyarakat Indonesia, istilah etika dikaitkan dengan moralitas seseorang. Orang yang tidak mempunyai etika yang baik sering dinilai tidak mempunyai moral karena semua perkataan dan tindakannya tidak diambil melalui pertimbangan baik dan buruk, pantas dan tidak. Tidak adanya filter pertimbangan nilai baik dan buruk serta pantas dan tidak ini merupakan awal adanya bencana dalam pemanfaatan media sosial.

Etika komunikasi dalam media sosial jika diimplementasikan antara lain dapat diketahui dari komunikasi yang santun. Hal ini merupakan cerminan dari adanya kesantunan kepribadian dalam berkomunikasi di

\footnotetext{
22 Ika Destiana \& Ali Salman, "The Acceptance, Usage And Impact Of Social Media Among University Students", Journal of Social Sciences And Humanities, Special Issue 1, 2015, 1.
} 
media sosial. Komunikasi dalam media sosial diibaratkan seperti urat nadi penghubung untuk terciptanya kehidupan yang menjadi salah satu ekspresi dan karakter dan sifat seseorang untuk saling berinteraksi serta bekerja sama. Untuk bisa saling mengerti dan memahami apa yang dipikirkan, dikehendaki, dirasakan orang melalui komunikasi yang diekspresikan dengan menggunakan apa yang dia lakukan dan katakan. Pesan yang ingin disampaikan melalui komunikasi bisa berdampak positif maupun negatif. Komunikasi akan bernilai positif, jika lawan komunikasi mengetahui dan mempraktikkan teknik berkomunikasi yang baik dan etika komunikasi.

Dalam etika berkomunikasi tidak hanya berkaitan dengan tutur kata yang baik saja, namun juga harus berangkat dari niat yang tulus yang kemudian diekspresikan dengan empati dalam berkomunikasi. Bentuk komunikasi yang demikian akan menghasilkan komunikasi yang saling menghargai antar pihak yang berkomunikasi. Komunikasi yang menggunakan etika hari ini menjadi hal yang sangat asing dan penting untuk digalakkan. Dalam kesehariannya, perilaku komunikasi masih sering dijumpai sejumlah hal yang mencerminkan dari perilaku komunikasi yang tidak santun dan tidak beretika. Etika komunikasi sering dipinggirkan, karena etika komunikasi belum menjadi budaya sebagai urat nadi dari kehidupan berbangsa dan bernegara. ${ }^{23}$

Dalam ajaran Islam, memberikan dan membagikan informasi mutlak diperlukan. Karena melalui penyampaian informasi itulah masyarakat bisa memeroleh berbagai pengetahuan untuk meningkatkan pengetahuannya. Dalam tinjauan dan pendekatan maqashid syari'ah pada media sosial ini supaya aktivitas media sosial tidak terkesan kaku dan tidak terjerumus pada hal-hal yang bertentangan dengan tujuan-tujuan syari'at (maqashid syari'ah). Hal ini dikarenakan media sosial relatif abstrak, sehingga diperlukan pendekatan dari syari'at.

Dalam hal mewujudkan maqashid syari'ah, seseorang dalam hal menyampaikan berita di media sosial harus mempunyai pertimbangan manfaat (maslahah), serta tidak menimbulkan kebencian (mafsadat), dikarenakan esensi dari maqashid syari'ah adalah mewujudkan kemaslahatan dan menolak pada kerusakan. ${ }^{24}$ Rambu-rambu penyampaian berita ini sesuai dengan yang disampaikan oleh Nabi Muhammad, "Muslim sejati ialah seseorang yang menyelamatkan muslim lainnya dari mulut dan

\footnotetext{
${ }^{23}$ Beberapa problematika dan permasalaha komunikasi di media sosial disebabkan oleh rendahnya literasi digital dan pengetahuan serta kurangnya etika dalam berkomunikasi. Lihat, Puji Rianto, "Literasi Digital Dan Etika Media Sosial Di Era Post-Truth", Interaksi: Jurnal Ilmu Komunikasi, Volume 8, Nomor 2, Desember 2019, 31-32.

${ }^{24}$ Hasan Abu Thalib, Tatbiq al-Syari'ah al-Islamiyah Fi Balad al-'Arabiyah. (Beirut: Dar al-Nahdah al-'Arabiyah, 2010), 27.
} 
tangannya" (HR. Muslim). ${ }^{25}$ Hal ini menunjukkan bahwa etika dalam bermedia sosial sesuai dengan teks-teks agama Islam.

Dalam hal informasi, sebuah informasi bisa benar jika dipertimbangkan dengan dampak positif maupun negatif jika informasi tersebut disebarluaskan, terutama melalui media sosial. Seperti pada peristiwa Rasulullah ketika memberi kabar kepada Mu'adz bin Jabal tentang hak Allah bagi para hamba-Nya ialah bahwa mereka harus menyembah-Nya dan tidak menyekutukan-Nya dengan hal lain. Sebaliknya hak hamba Allah ialah untuk tidak menyiksa hamba yang bersatu dan tidak bergaul dengan siapa pun. Ketika itu Mu'adz bin Jabar meminta izin kepada Nabi untuk memberitakan hal itu kepada sahabat-sahabat lain. Tapi Nabi justru melarangnya dengan berkata, "Jangan berkhotbah tentang hal ini kepada mereka, dikhawatirkan mereka salah paham" HR. Bukhari). ${ }^{26}$ Informasi dan berita ini benar, akan tetapi Rasulullah memiliki pertimbangan lain, beliau khawatir informasi tersebut membahayakan dan akan terjadi saling fitnah di antara mereka. Sebab kondisi masyarakat saat itu belum siap menerima informasi tersebut. Dikarenakan tidak semua orang mempunyai pemahaman yang sama, seperti yang telah dipahami oleh Mu'adz bin Jabal. Peristiwa ini menunjukkan serta menekankan bahwa aktivitas media sosial perlu menerapkan pertimbangan yang membawa maslahah yang berupakan tujuan dari syari'at Islam (maqashid syari'ah).

Maqashid syari'ah yang terangkum dalam lima hal mendasar (dharuriyat atau kulliyat al-khams) menurut al-Syatibi seperti simbiosis mutualisme antara yang wujud dengan yang 'adam antara yang ada dan yang tidak ada. Jika adanya manusia itu terjaga maka kehidupan ini akan terjaga pula, namun jika manusia itu musnah atau binasa maka kehidupan juga akan berakhir dan sirna. Maka kelima unsur fundamental ini adalah prinsip dasar hak asasi manusia (HAM) dalam agama Islam. Adapun untuk mewujudkan kelima unsur tersebut al-Syatibi memberikan dua solusi. Pertama, menjaga agar keberadaannya bisa aman dan langgeng (min nahiyat al wujud) dan menjaga dan mencegah dari segala hal yang bisa merusak dan meniadakannya (min nahiyati al adam).

Hifz al-din (memelihara agama) ialah berupa pemeliharaan terhadap iman, Islam dan ihsan. Bahwa seorang muslim harus bisa menjaga agama dan aqidahnya dari segala hal yang bisa menghilangkannya. Hifz al-nafs (memelihara jiwa) ialah dengan menjaga keselamatan dan kehidupan manusia baik berupa makanan, minuman (yang memelihara dari dalam)

25 Muslim Ibn Hijjaj, Shahih Muslim Jilid VI. (Beirut: Dar al-Kutub al-Ilmiah, t.t.), 110. 79.

26 Muhammad Ibn Ismail al-Bukhari, Shahih Bukhari Jilid II. (Kairo: Dar al-Hadits, t.t.), 
maupun berupa pakaian dan tempat tinggal (yang memelihara dari luar) dan memelihara dari segala hal yang bisa membahayakan dan mengancamnya seperti pembunuhan. Hifz al-'aql (memelihara akal) seperti perintah untuk belajar dan diharamkannya minuman keras dan narkoba. Hifz al-nasl (memelihara keturunan) seperti disyariatkannya nikah dan diharamkannya zina. Serta hifz al-mal (memelihara harta) dengan adanya larangan mencuri, merampok dan lain sebagainya.

Terlepas dari konsep di atas, konsep maqashid syari'ah klasik lebih banyak menyoal tentang garis besar tujuan lahirnya hukum syara' dan mekanisme pengambilan hukum dengan bersandar pada prinsip-prinsip maqashid. Seiring dengan perkembangan zaman, telah terjadi pergesaran pemahaman tentang makna dan paradigma maqashid syari'ah. Pergesaran makna dan paradigma maqashid ini muncul seiring perubahan kondisi dan situasi zaman. Pergeseran paradigma maqashid dari klasik menuju modern ini terletak pada fokus titik tekan dan kajiannya. Adapun fokus teori maqashid klasik lebih pada perlindungan (protection), penjagaan atau pelestarian (preservation). Sedangkan teori maqashid modern di samping juga tetap memperhatikan aspek tersebut namun pembahasannya semakin melebar dengan mengarah kepada aspek pembangunan atau pengembangan (development) dan hak-hak manusia (human right). Kemudian paradigma maqashid modern ini menghasilkan aspek pembangunan dan pengembangan berupa hifz al-bi'ah (menjaga lingkungan) dan pada pembangunan hak asasi manusia berupa hifz al-ird (menjaga harga diri). Sebagai upaya mentransformasikan konsep maqashid syari'ah sebagai upaya membangun aktifitas media sosial yang beretika, penulis memberikan elaborasi sebagai berikut:

1. Hifz al-din (menjaga agama), menjaga agama ini menjadi rambu-rambu dalam menciptakan komunikasi di media sosial, jika terjadi saling hujat, cemoohan antar pemeluk agama dan kelompok dalam komunikasi di media sosial, maka akan menimbulkan sebuah pertikaian antar pemeluk agama dan kelompok, sehingga hakikat agama yang mengusung nilai-nilai perdamaian dan kemaslahatan tidak bisa terwujud.

2. Hifz al-nafs (menjaga jiwa), menjaga jiwa (nyawa) tidak bisa terwujud jika terjadi saling hujat dalam aktivitas media sosial, sehingga menimbulkan gejolak pertikaian yang membuat jiwa manusia menjadi terancam.

3. Hifz al-'aql (menjaga akal), hakikat membangun etika pada aktivitas komunikasi dalam media sosial adalah untuk menjaga akal manusia dari penurunan kualitas akal dan mengembangkan akal manusia pada hal positif berupa meningkatkan pengetahuan yang diaktualisasikan berupa komunikasi yang beretika. 
4. Hifz al-nasl (menjaga keturunan), aktivitas komunikasi dalam media sosial yang tidak beretika, akan mewariskan suatu hal yang negatif bagi anak keturunan, sehingga hal ini sangat mencederai marwah menjaga anak keturunan dari hal yang negatif.

5. Hifz al-mal (menjaga harta), ancaman terhadap harta bisa terjadi jika salah dan kurang bijak dalam berkomunikasi di media sosial, sebagaimana terancamnya nyawa dan ketenteraman hidup manusia.

6. hifz al-bi'ah (menjaga lingkungan), lingkungan dan sumber daya alam akan terancam jika terjadi suatu pertikaian yang disebabkan oleh proses komunikasi yang saling cemooh, hujat menghujat, dan unsur kebencian.

7. Hifz al-'ird (menjaga harga diri), untuk menjaga harkat dan martabat manusia salah satunya melalui komunikasi di media sosial yang beretika, karena komunikasi semacam ini bisa diketahui oleh dunia luas, oleh karenanya memfitnah, menghujat orang lain akan menghancurkan harga dirinya pada dunia luas.

\section{Kesimpulan}

Kemajuan teknologi menjadi suatu hal yang tidak dielakkan oleh generasi hari ini, sehingga penggunaan media sosial yang merupakan dampak dari kemajuan teknologi menjadi hal yang sangat lazim dan lumrah. Namun demikian, dalam penggunaan media sosial ini masih cenderung disalah gunakan pada hal-hal yang negatif. Hal ini bisa ditemukan dari beberapa kasus yang berujung pada pelanggaran hukum yang bermula dari penggunaan media sosial yang tidak menggunakan etika. Maqashid syari'ah sebagai ruh dari kajian hukum Islam telah mampu menemukan posisinya dalam rangka membangun aktivitas media sosial berdasarkan nilai-nilai fundamental dalam menciptakan kemaslahatan bagi seluruh manusia, yaitu melindungi agama, jiwa, akal, keturunan, harta, lingkungan, serta kehormatan.

Penelitian ini hanya mengulas dan memberikan elaborasi secara teoritis dari konsep maqashid syari'ah untuk membangun aktivitas media sosial yang berlandaskan etika secara umum. Peneliti berharap temuan dalam penelitian ini bisa dikembangkan dan bisa diaktualisasikan dari setiap perlindungan maqashid syari'ah kepada setiap pelanggaran etika melalui media sosial. Sehingga akan menghasilkan temuan penelitian berupa solusi atas problematik pelanggaran melalui media sosial yang berdasarkan pada nilai-nilai fundamental maqashid syari'ah. 


\section{Daftar Pustaka}

Al-Bukhari, Muhammad Ibn Ismail. Shahih Bukhari Jilid II. Kairo: Dar alHadits, t.t.

Al-Syatiby, Abu Ishaq. Al-Muwafaqat Fi Ushul al-Syari'ah. Beirut: Dar alMa;rifah, 2000.

Al-Qaradlawi, Yusuf. Al-Ijtihad Fi al-Syari'ah al-Islamiyah Ma'a Nazhrati Tahliliyah Fi al-Ijtihad al-Mu'ashir. Kuwait: Dar al-Qalam, 2000.

Alfani, Arif dan Hasep Saputra. "Menghujat dan Menista di Media Sosial Perspektif Hukum Islam", Al-Istimbath: Jurnal Hukum Islam, Volume 4, Nomor 1, 2019.

Ashofa, Burhan. Metode Penelitian Hukum. Jakarta: Rineka Cipta, 2010.

Asyur, Muhammad Thahir Ibnu. Maqashid al-Syari'ah al-Islamiyah. Beirut: Dal al-Qalam, 2009.

Aswan. "Tekno-Culture: Memahami Kondisi Masyarakat Masa Depan”, Palita: Journal of Social-Religion Research, Volume 2, Nomor 1, April 2017.

Bungin, Burhan. Penelitian Kualitatif. Jakarta: Kencana Prenada Media Group, 2010.

Destiana, Ika \& Ali Salman. "The Acceptance, Usage And Impact Of Social Media Among University Students", Journal of Social Sciences And Humanities, Special Issue 1, 2015.

Hasaballah, Ali. Ushul al-Tasyri' al-Islam. Mesir: Dar al-Ma'arif, 2003.

Hasan, Husein Hamid. Nadzariyah al-Maslahah Fi al-Fiqh al-Islamy. Beirut: Muassasah al-Risalah, 2001.

Hijjaj, Muslim Ibn. Shahih Muslim Jilid VI. Beirut: Dar al-Kutub al-Ilmiah, t.t.

J., Cresswell. Reseach Design: Qualitative \& Quantitative Approaches. Thousand Oaks: Sage Publication, 1998.

Josef, Jani. To Be A Jurnalist: Menjadi Jurnalis TV, Radio, dan Surat Kabar Yang Profesional. Jogjakarta: Graha Ilmu, 2009.

Kementerian Agama RI. Al-Qur'an Dan Terjemahnya. Semarang: CV, Tanjung Mas, 2010. 
Khalik, Subehan. "Hukum Islam dan Penggunaan Telematika di Indonesia", alDaulah: Jurnal Hukum Pidana dan Ketatanegaraan, Volume 1, Nomor 1, 2012.

Kompas.com, Sejak 21 Mei, Polri Tangkap 10 Tersangka Penyebar Hoaks dan Ujaran Kebencian, kabar pada hari, Selasa, 28 Mei 2019

Rianto, Puji. "Literasi Digital Dan Etika Media Sosial Di Era Post-Truth", Interaksi: Jurnal Ilmu Komunikasi, Volume 8, Nomor 2, Desember 2019.

Rianto, Puji. "Literasi Digital Dan Etika Media Sosial Di Era Post-Truth", Interaksi: Jurnal Ilmu Komunikasi, Volume 8, Nomor 2, Desember 2019.

Setyawan, Hendra A. "Fikih Informasi Di Era Media Sosial Dalam Membangun Komunikasi Beretika (Studi Kajian Fikih Informasi Sudut Pandang Ormas Muhammadiyah", Disampaikan Dalam Seminar Nasional Tentang "Membangun Etika Sosial Politik Menuju Masyarakat Yang Berkeadilan", yang dilaksanakan oleh FISIP Universitas Lampung Pada Tanggal, 18 Oktober 2017 di Hotel Swiss Bell, Bandar Lampung,

Sumadi, Eko. "Dakwah Dan Media Sosial: Menebar Kebaikan Tanpa Diskriminasi", At-Tabsyir: Jurnal Komunikasi Penyiaran Islam, Volume 4, Nomor 1, Juni 2016.

Tambaruka, Apriadi. Literasi Media: Cerdas Bermedia Khalayak Media Massa. Jakarta: Raja Grafindo Persada, 2003.

Thalib, Hasan Abu. Tatbiq al-Syari'ah al-Islamiyah Fi Balad al-'Arabiyah. Beirut: Dar al-Nahdah al-'Arabiyah, 2010.

Tohari, Chamim. "Pembaharuan Maqashid Syari'ah Dalam Pemikiran Muhammad Thahir Ibn 'Asyur", Al-Maslahah: Jurnal Ilmu Syari'ah, Volume 13, Nomor 1, April 2017.

Ula, Siti Khoirotul. "Fikih Media Sosial Sebagai Landasan Etika Komunikasi On-Line", Peoceedings Ancoms 2017, UIN Sunan Ampel Surabaya.

Wulandari, Fajrina eka. "Hate Speech Dalam Pandangan UU ITE Dan Fatwa MUI", Ahkam: Jurnal Hukum Islam, Volume 5, Nomor 2, November 2017.

Zainuddin, Ali. Metode Penelitian Hukum. Jakarta: Sinar Grafika, 2014. 